\title{
Astrocyte Growth Is Regulated by Neuropeptides through Tis 8 and Basic Fibroblast Growth Factor
}

\author{
Ren-Ming Hu and Ellis R Levin \\ Departments of Medicine and Pharmacology, University of California at Irvine, Irvine, California 92717; \\ and Long Beach Veterans Administration Hospital, Long Beach, California 90822
}

\begin{abstract}
The important intracellular mechanisms of astrocyte growth are not well defined. Using an inhibitor of astrocyte proliferation, atrial natriuretic peptide (ANP), and the glial mitogen endothelin (ET-3), we sought a common pathway for growth regulation in these neural cells. In cultured fetal rat diencephalic astrocytes, ANP selectively and rapidly inhibited the Tis 8 immediate early gene and protein. After $4 \mathrm{~h}$, ANP selectively inhibited the basic fibroblast growth factor (bFGF) gene and protein. ET-3 significantly stimulated both Tis 8 and bFGF mRNAs and protein, but also stimulated several other immediate early and growth factor / receptor genes. An antisense oligonucleotide to Tis 8 strongly prevented ET-stimulated thymidine incorporation, while the inhibitory action of ANP was enhanced. The Tis 8 antisense oligonucleotide also significantly reversed ET-stimulated bFGF transcription and enhanced the bFGF inhibition caused by ANP. In addition, an antisense oligonucleotide to bFGF significantly reversed the ET-stimulated thymidine incorporation and enhanced the ANP inhibition of DNA synthesis. The sequential modulation of Tis 8 , followed by bFGF, provides a novel mechanism for both positive and negative regulation of astrocyte growth by endogenous neuropeptides. (J. Clin. Invest. 1994. 93:1820-1827.) Key words: astrocyte $\bullet$ atrial natriuretic peptide $\bullet$ endothelin $\cdot$ cell proliferation • growth factor
\end{abstract}

\section{Introduction}

Astrocytes in the central nervous system normally proliferate only during fetal life. Growth modulation at that time results, in part, from the action of peptide growth factors produced in various central nervous system cells, including glia. The response by astrocytes to extracellular growth stimuli includes the production and subsequent action of autocrine growth factors, produced through a cascade of poorly defined intracellular events. It is likely that immediate early gene activation and protein synthesis precedes and modulates the enhanced growth factor production in these cells (1-3). Growth restraint could result from either the programmed cessation or the direct inhibition of the proliferative process.

Address correspondence to Ellis R. Levin, M.D., Medical Service (111I), Long Beach Veterans Hospital, 5901 East Seventh Street, Long Beach, CA 90822.

Received for publication 1 July 1993 and in revised form 29 October 1993.

The Journal of Clinical Investigation, Inc.

Volume 93, April 1994, 1820-1827
Atrial natriuretic peptide (ANP) ${ }^{1}$ is a peptide hormone synthesized in fetal and adult diencephalic neurons $(4,5)$ that binds to and acts as an anti-growth factor for astrocytes in vitro $(6,7)$. Endothelin-3 (ET-3) is a vasoactive peptide synthesized in diencephalic neurons and glia $(8,9)$ that binds to astrocytes and neurons $(10,11)$, and stimulates DNA synthesis in cultured glia (12, 13). Since ANP and ET modulate the proliferation of diencephalic astrocytes in culture, we reasoned that they might do so through a common mechanism involving the regulation of growth-related genes. The presence of a mature system of neuropeptide synthesis, processing, and receptor expression for ANP and ET in vivo by gestational day 15 in the rat, implies that these two peptide neurotransmitters play a role in fetal brain development (14).

Specific immediate early genes such as c-fos, c-myc, and $c-j u n$ have been implicated in the growth of various cells (1517). In the brain, treatment of astrocytes with the growth promoting phorbol esters strongly increases the expression of a series of immediate early genes. These TPA-inducible sequences or Tis genes (18) include two genes that are also inducible by neural growth factor (NGF), NGFIB (Tis 1), and NGFIA (Tis 8): The latter is the rat homologue of egr-1, (or krox 24 or zif 268) in other cell types (19-22). Tis 1 and Tis 8 are known transcription factors, binding via zinc fingers to DNA, and Tis 8 (egr-1), in particular, has been implicated in the regulation of cell growth (23). It has not been established that these immediate early genes play a role in neural cell growth, and no target genes that are transcriptionally regulated by these proteins have been identified. Thus, in these studies, we attempted to deduce an intracellular pathway by which the endogenous neuropeptides ANP and ET regulate astrocyte proliferation, involving discrete immediate early and growth factor protein production.

\section{Methods}

Materials. cDNA probes for the TIS genes were kindly provided by Dr. Harvey Herschman, UCLA (24), c-myc, c-jun, and EGF-R were from American Type Culture Collection (Rockville, MD) $(25,26)$, bFGF from Dr. Andrew Baird, Scripps Institute (La Jolla, CA) (27), PDGFA from Dr. Cecelia Giachelli, University of Washington, (Seattle, WA) (28), and IGF-1 from Dr. Charles Roberts, National Institutes of Health (Bethesda, MD) (29). B-actin cDNA was provided by Dr. Paul Isackson. Ribiprobe RNA transcription kit was from Stratagene (La Jolla, CA). ${ }^{32}$ P-labeled nucleotides were from Amersham Corp. (Arlington Heights, IL). $\left[{ }^{3} \mathrm{H}\right]$ Thymidine was from NEN Du Pont, (Wilmington, DE).

Cell culture and experiments. The diencephalic area of the brain (85\% hypothalamus) was carefully isolated from 16-d gestational fetal rats and mechanically and enzymatically dispersed as previously de-

1. Abbreviations used in this paper: ANP, atrial natriuretic peptide; bFGF, basic fibroblast growth factor; EGF-R, epidermal growth factor receptor; ET-3, endothelin-3. 
scribed $(7,30)$. This approach yields a culture that is $\sim 95 \%$ glia by light microscopy after immunochemical staining for glial acidic fibrillary protein (30). Cultures were also trypsinized and replated to yield first passage cultures that were $99 \%$ astrocytes, and data from primary or first passage astrocytes was identical. The cells were then plated in DME/F12 medium with 10\% FBS. Studies using glia were typically carried out 10-14 d after plating. Astrocytes were incubated in the presence or absence of ANP, PMA, or ET-3, $10^{-7} \mathrm{M}$ or $10^{-9} \mathrm{M}$, for various times up to $2 \mathrm{~h}$ (immediate early genes) or as long as $8-24 \mathrm{~h}$ (growth factor genes).

SI nuclease protection. The RNA from astrocytes cultured under the experimental conditions was extracted and the expression of the various genes under these conditions was determined after hybridization of labeled cRNA antisense probes with the experimental RNA. This was followed by $\mathrm{S} 1$ nuclease digestion, separation of hybridized complexes by electrophoresis on denaturing polyacrylamide gel, and autoradiography, as previously described in detail $(31,32)$. Sense probes produced no hybridization. The constructs of the various probes used were given in previous publications (see Methods).

Nuclear run on assay. For nuclear run on, astrocytes were incubated in the presence or absence of ANP or ET, with or without an antisense construct for Tis 8 (see below) for $4 \mathrm{~h}$. The cells were washed, then lysed in NP-40 lysis buffer. The nuclei were isolated after centrifugation, followed by freezing in glycerol storage buffer until use. As previously described for transcription studies (32), the thawed nuclei $\left(5 \times 10^{7}\right.$ cells $)$ were added to equal volume reaction buffer with $4 \mathrm{mM}$ ATP, GTP, and CTP plus $10 \mu \mathrm{l}$ of [ $\left.{ }^{32} \mathrm{P}\right]$ UTP. After a 30 -min incubation, the DNA was digested with DNase, followed by proteinase $\mathrm{K}$ digestion. The newly formed, ${ }^{32} \mathrm{P}$-labeled RNA was then purified and precipitated, then transferred onto HA filters (Whatman Inc., Clifton, $\mathrm{NJ}$ ) and the RNA eluted. An aliquot of the RNA was counted and equal counts of labeled nuclear RNA from each experimental condition were hybridized with the cDNA for bFGF, spotted onto nitrocellulose filters (using a slot blot apparatus). Comparison was made using a cDNA for B-actin. After $36 \mathrm{~h}$ of hybridization, the filters were washed, RNase treated, and exposed to $\mathrm{x}$-ray film for $1-3 \mathrm{~d}$.

Antisense studies. For DNA synthesis experiments, astrocytes were incubated for $18 \mathrm{~h}$ with a 19-mer phosphorothionated antisense oligonucleotide directed to the coding region for TIS 8, commencing with the initiation ATG (5' CGG CCT TGG CCG CTG CCAT 3') (33), at various concentrations, before the addition of ET or ANP. As controls, a sense oligonucleotide ( $5^{\prime}$ ATG GCA GCG GCC AAG GCC G 3') to Tis 8 or an antisense oligonucleotide for c-myc (5' AAC GTT GAG GGG CAT $\left.3^{\prime}\right)$ was also used. We similarly incubated the cells with antisense (5' GGC AGC CAT GGC CCC 3') or sense (5' GGG GCC ATG GCT GCC $3^{\prime}$ ) oligonucleotides to rat bFGF (21), $18 \mathrm{~h}$ before ANP or ET. The cells were then incubated with neuropeptides for $24 \mathrm{~h}$. At $20 \mathrm{~h}$, the cells were pulsed with $0.1 \mu \mathrm{Ci}$ of $\left[{ }^{3} \mathrm{H}\right]$ thymidine (specific activity $20 \mathrm{Ci} / \mathrm{mmol}$ ) per well for $4 \mathrm{~h}$, the cells were washed with PBS, incubated with $10 \%$ TCA, and harvested after overnight incubation in $0.5 \mathrm{ml}$ of $0.2 \mathrm{~N} \mathrm{NaOH}$ (7). TCA-precipitated counts were determined in a beta counter (Beckman Instruments, Fullerton, CA), and normalized for protein (Lowery). The same constructs were used for the effects on gene expression, determined by nuclear run-on and protection assay; preincubation of the astrocytes with the constructs for $18 \mathrm{~h}$ preceded neuropeptide addition.

Western blotting. Glia were incubated in the presence or absence of the neuropeptides for 90 or $120 \mathrm{~min}$ ( Tis 8 ), or for $4 \mathrm{~h}$ (bFGF) in the presence or absence of ASO or sense constructs. The cellular protein was extracted and quantified, then $20 \mu \mathrm{g} /$ lane was separated by SDSPAGE ( $12 \%$ gel with $10 \%$ SDS) and transferred to nitrocellulose. The protein was detected by immunoblot (Tropix, Bedford, MA), using a first monoclonal antibody to Egr-1 (Amgen, Thousand Oaks, CA) or bFGF (Dr. C. Hart, Zymogenetics, Seattle, WA), at 1:500 dilution, and quantified by laser densitometry.

Data analysis. RNA comparisons were quantified by laser densitometry of autoradiographs, and data was normalized for RNA loading by creating a ratio of the density of the experimental RNA hybridized with the cRNA probe (e.g., Tis 8 ), divided by the density of the same amount of RNA hybridized with an $\mathrm{H}$ - ras probe. A ratio was then established by comparing normalized experimental RNA to normalized control RNA that was extracted from nontreated astrocytes. A value of 1 was arbitrarily assigned to the control. This resulted in values expressing the relative densities of the experimental conditions compared to the control. Densitometry of protein bands was also used to quantitate the effects of neuropeptides or antisense constructs on protein expression in the astrocytes. All values presented are the mean \pm SEM of data combined from three experiments.

\section{Results}

Immediate early gene expression. We first determined which immediate early genes are modulated in their expression by ANP and ET, and therefore, might be involved in the growth regulatory effects of these peptides. After 60 min of incubation with cultured diencephalic astrocytes, ANP inhibited the basalor phorbol ester-stimulated expression of Tis 8 by $\sim 60 \pm 03$ and $70 \pm 04$ (SEM) \%, respectively (Fig. 1 $A$ ). This effect was selective, since ANP had no inhibitory effect on basal c- fos, c-myc, c-jun, or Tis 1 gene expression in our screening studies. In contrast, ET-3 stimulated Tis 8 expression by $2.4 \pm 0.3-$ fold (Fig. $1 B$ ) during the same time course, but also comparably augmented c-fos, c-jun, and c-myc expression in the astrocytes: Tis 1 was not stimulated by ET-3 (data not shown). Consistent with the effects on mRNA, ANP inhibited Tis 8 protein in the glia by $51 \pm 04 \%$, while ET stimulated it by $80 \pm 02 \%$, (Fig. $2 A$ ). These experiments suggested that Tis 8 , by itself or in conjunction with other rapidly induced genes, might participate in the modulation of astrocyte growth by both mitogenic or growthinhibiting endogenous neuropeptides.

Autologous growth factor expression. We then assessed which astrocyte-synthesized growth factors or receptors may be modulated by ANP and ET and, therefore, might serve as autologous growth promoting proteins for these cells. Several candidate proteins have been implicated in the growth of glia or glial-derived tumors, including PDGF-A, EGF-R, IGF-1, and bFGF (34-41). We found that ANP inhibited the transcription of the bFGF gene by $\sim 45 \%$ after $4 \mathrm{~h}$ of incubation, (Fig. $3 \mathrm{~A}$ ). In our screening studies, ANP had no inhibitory effect on PDGF-A, EGF-R, or IGF-1. ET-3 caused a 2.0 \pm 0.2 -fold increase in bFGF transcription (Fig. $3 \mathrm{~A}$ ), but also stimulated IGF- 1 and EGF-R gene expression in astrocytes (data not shown). Taken together, the results pointed toward bFGF as the leading candidate for the endogenous growth factor that mediates these actions of ANP and ET, although other proteins, alone or in combination with bFGF, might contribute to this process.

Tis-8 effects on bFGF and DNA synthesis. To establish a definitive role for Tis 8 in first modulating bFGF gene expression and then astrocyte growth, we inhibited the production of the Tis 8 protein by using an antisense oligonucleotide (ASO) for this gene (33). We first determined in preliminary experiments that inhibition of Tis 8 protein production in astrocytes by the ASO was dose related, including $80 \%$ at a concentration of $1 \mu \mathrm{M}$. So as not to obscure the effects of the neuropeptides (ANP or ET), we chose a concentration of $0.25 \mu \mathrm{M}$ Tis 8 ASO, which inhibited the basal Tis 8 protein by $30 \pm 7 \%$ (Fig. $2 \mathrm{~B}$ ), based on three experiments combined. The Tis $8 \mathrm{ASO}$ at this concentration nearly completely prevented the ET-3 stimulation of Tis 8 protein, which was $78 \pm 6 \%$ above control (Fig. $2 B$, lanes 1 vs 2 vs 3 ). In contrast, the control Tis 8 sense construct had no significant effect on ET-3-stimulated Tis 8 production (Fig. $2 B$ ). 


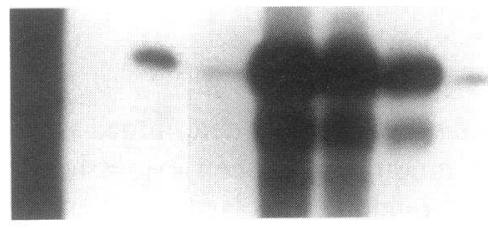

$\begin{array}{llllllll}1 & 2 & 3 & 4 & 5 & 6 & 7 & 8\end{array}$

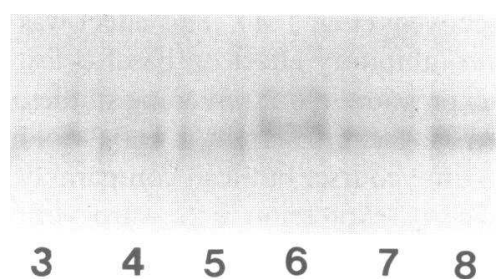

B
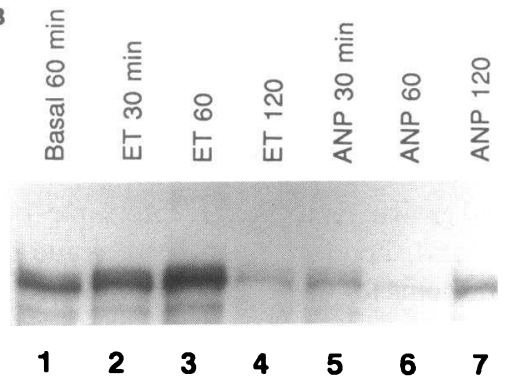

ET and inhibition by ANP. Lane 1, basal expression at $60 \mathrm{~min}$ in medium; lanes 2-4, ET-3 $10^{-7} \mathrm{M}$ for 30,60 , and $120 \mathrm{~min}$, respectively; lanes $5-7$, ANP $10^{-7} \mathrm{M}$ for the same times. Hybridization density values in the text represent the mean of three experiments with a standard error of $<5 \%$.

Establishing the validity of using this ASO construct, we then determined that the ability of ET-3 to stimulate bFGF gene transcription was $\sim 85 \%$ inhibited by the Tis 8 ASO (Fig. $3 A$, and $3 B[i$, lanes $1-3])$ : This stimulation was unaffected by an antisense oligonucleotide to c-myc (Fig. $3 B$, $[i$, lane 2] vs [ii, lane 4]). These experiments are quantified in Fig. 4. The stimulation of bFGF protein production by ET ( $70 \pm 4 \%$ increase compared to control cells) was completely inhibited by the Tis 8 ASO (Fig. $5 A$ ), supporting this specific mechanism of the ASO effect.

This ASO, in dose-related fashion, also significantly limited the ability of ET-3 to promote DNA synthesis (Fig. $6 \mathrm{~A}$ ). ET caused a $2.5 \pm 0.2$-fold increase in thymidine incorporation, which was $75 \pm 5 \%$ reversed by the addition of the Tis $8 \mathrm{ASO}$ at this concentration. In contrast, a corresponding sense oligonucleotide did not significantly inhibit Tis 8 protein production, and importantly, had little effect on the increased bFGF gene expression or DNA synthesis caused by ET (Figs. 4-6). These results indicate that stimulation of Tis 8 by ET-3 is a critical event and is sufficient to explain most of the astrocyte growth-

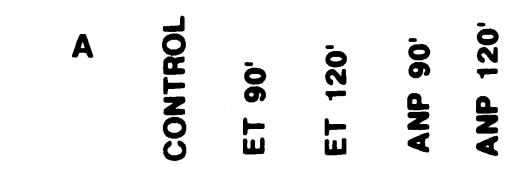

Figure 2. Western Blot of Tis 8 protein in astrocytes. $(A)$ Tis 8 protein in astrocytes in response to ANP or ET-3. Glia were incubated in

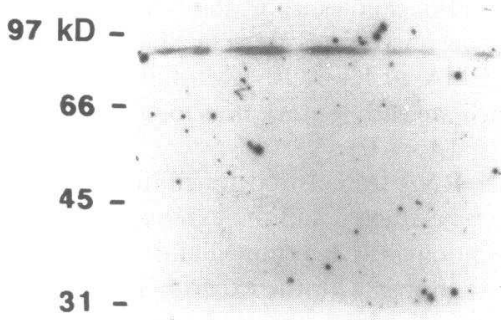

$\begin{array}{lllll}1 & 2 & 3 & 4 & 5\end{array}$

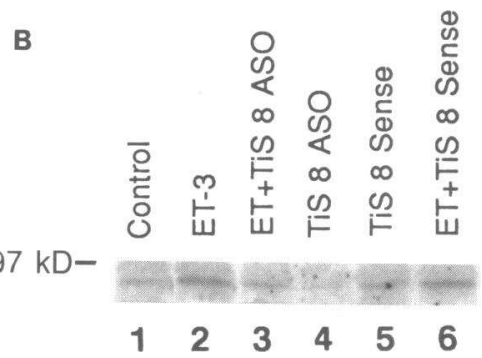
the presence or absence of the neuropeptides for 90 or $120 \mathrm{~min}$. The cellular protein was extracted and quantified, separated by SDSPAGE and the protein was detected by immunoblot (Tropix, Bedford, MA), using a first monoclonal antibody to Egr-1 (Amgen, Thousand Oaks, CA) at 1:500 dilution. The study was repeated twice and densitometric values combined for final quantification. $(B)$ ET-stimulated Tis 8 protein is inhibited by the Tis 8 ASO. Lane 1 , control; lane 2, ET-3induced Tis 8 protein;

lane 3, ET-3 plus Tis $8 \mathrm{ASO}, 0.25 \mu \mathrm{M}$; lane 4, Tis 8 ASO alone; lane 5, ET-3 plus Tis 8 sense construct $0.25 \mu \mathrm{M}$; lane 6 , Tis 8 sense alone. The study was confirmed twice.

promoting and bFGF-stimulating actions of this neuropeptide. In general, increased Tis 8 production may be an important early step during astrocyte growth, since other growth factors (EGF and the mitogenic phorbol esters) can also strongly stimulate the expression of this gene in cultured astrocytes (42).

The effects of the ASO on ANP function were more complex. We postulated that the inhibitory effects of ANP on bFGF expression or astrocyte growth are dependent on first inhibiting Tis 8 . Therefore, complete inhibition of Tis 8 protein production by the ASO might limit the subsequent action of ANP, while partial and additive inhibition could augment these actions of ANP. In fact, in our preliminary experiments, the Tis 8 ASO at $1 \mu \mathrm{M}$, significantly inhibited the proliferation of the astrocytes and the ability of ANP to act as an anti-growth factor for these cells. Therefore, to obscure the effects of ANP, we purposefully chose the concentrations of ASO used in this study on the basis of the pilot experiments described. We found that ANP inhibited bFGF mRNA levels by $50 \pm 2 \%$, and the Tis $8 \mathrm{ASO}, 0.25 \mu \mathrm{M}$, augmented this action to $75 \pm 6 \%$ (Fig. $3 C$, lanes $1-3$, and Fig. 4). ANP caused a $46 \pm 6 \%$ decrease in bFGF protein, which was augmented to $71 \pm 7 \%$ by the Tis 8 ASO (Fig. $5 \mathrm{~A}$, lanes 4 and 7). To support the idea that the ASO inhibits protein translation, we also showed that a higher concentration of the Tis $8 \mathrm{ASO}, 0.5 \mu \mathrm{M}$, by itself causes a $55 \%$ decrease in unstimulated bFGF protein production (Fig. $5 \mathrm{~A}$ ).

The Tis 8 ASO also augmented the ANP inhibition of thymidine incorporation in astrocytes from 35 to $50 \%$, but had little inhibitory effects by itself at $0.25 \mu \mathrm{M}$ (Fig. $6 \mathrm{~A}$ ). The control sense oligonucleotide did not augment the action of ANP, and an antisense oligonucleotide to c-myc had little effect on this parameter. Since the ASO increased the growth inhibition induced by ANP, our findings imply that the de- 

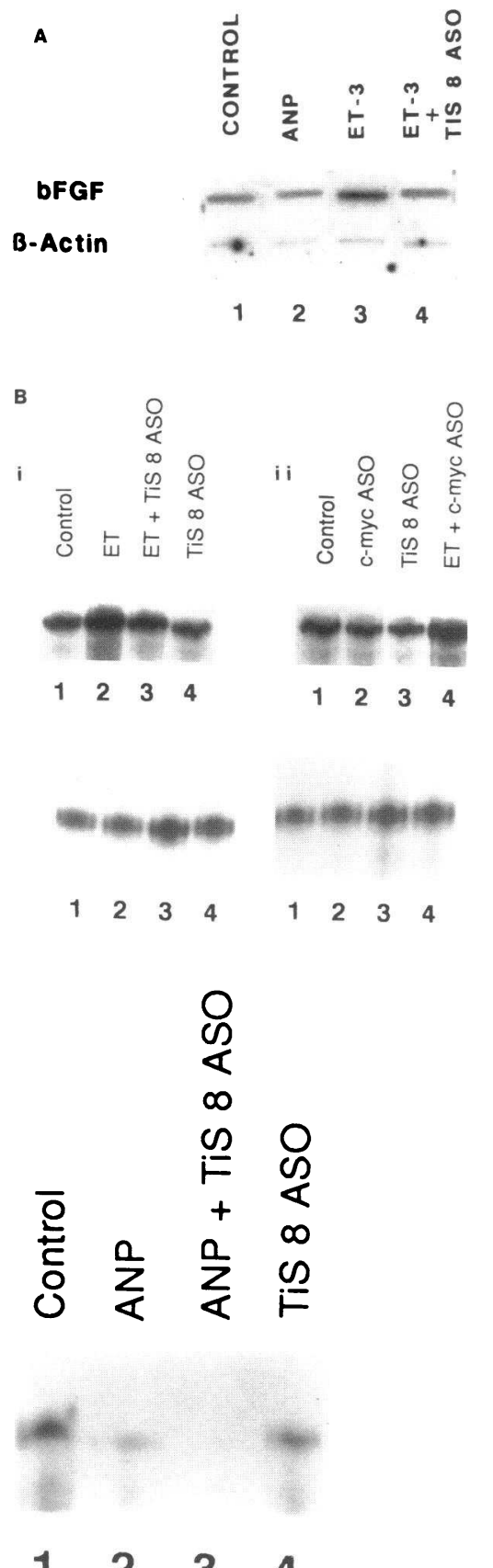

$\begin{array}{llll}1 & 2 & 3 & 4\end{array}$
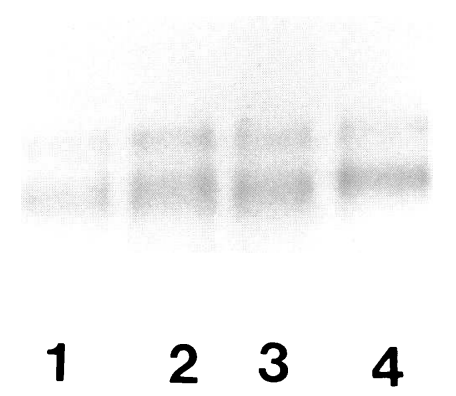

crease of Tis 8 protein production is necessary for ANP action. Interestingly, the mitogenic effects of a phorbol ester (which we and others have shown to stimulate Tis 8 production in glia) effect on ET-stimulateraction of ANP and Tis 8 ASO on bFGF gene expression. ( $T o p)$ Lanes $1-4$ are control, ANP, ANP plus Tis 8 ASO $0.25 \mu \mathrm{M}$, or the ASO alone. The corresponding hybridizations with a probe for $\mathrm{H}$-ras are shown below both $B$ and $C$. All experiments were repeated two or three times.

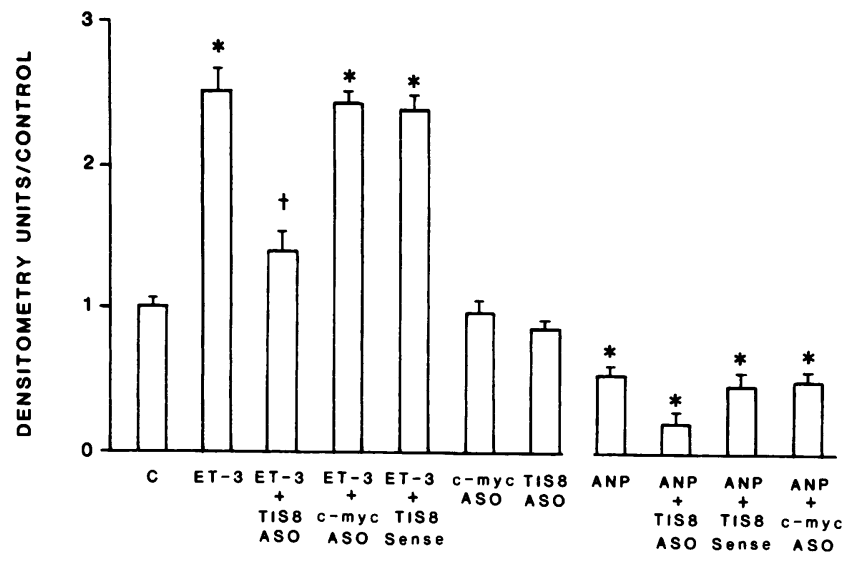

Figure 4. Quantitative effects of ANP and ET on bFGF mRNA levels. The ordinate provides a density value (in arbitrary units) for each experimental treatment. Each value was determined by first scanning the protected, hybridized band with laser densitometry, then normalizing this value for RNA loading, by comparing the signal from the same amount of experimental RNA hybridized to a cRNA probe for H-ras. This "RNA-loading normalized" value was then compared to control (nontreated) astrocyte expression of bFGF, also normalized for $\mathrm{H}$-ras. The control was then arbitrarily assigned a density of 1 , and all experimental densities were relatively adjusted, giving a final derived value. Each bar represents the mean \pm SEM values from three separate experiments combined. ${ }^{*} P<0.05$ for comparison with control by ANOVA plus Scheffe's test. $+P<0.05$ for ET-3 vs ET-3 plus Tis 8 ASO.

were significantly attenuated by ANP (Fig. $6 \mathrm{~A}$ ). In view of the role for Tis 8 in ET-stimulated bFGF and astrocyte proliferation, ANP could certainly inhibit bFGF production by first

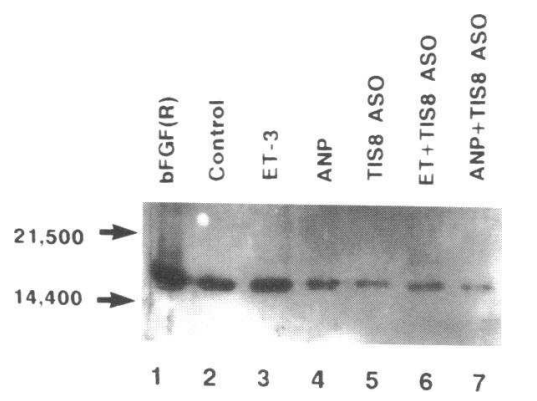

Figure 5. Basic FGF protein in astrocytes by Western immunoblot. The protein was detected using antibody to bFGF at 1:500 dilution. The densitometry values in the text represent the mean of three experiments combined with standard errors of $<6 \%$. $(A)$ Effect of
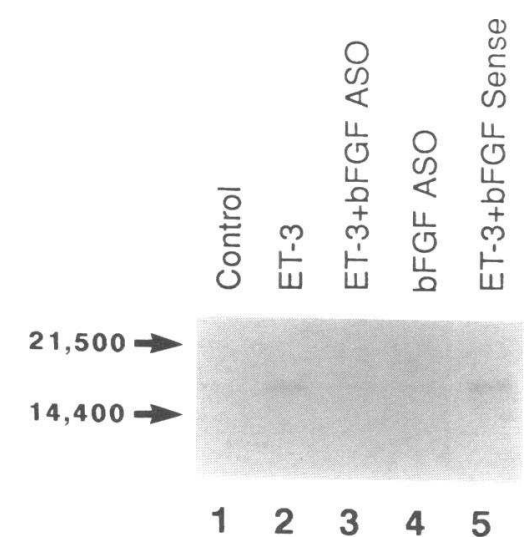

ANP, ET, or Tis 8 ASO on bFGF protein. Lane 1 , is recombinant bFGF (USB) as external control; lane 2, media-incubated (control) cell expression of bFGF; lane 3, ET-3 $10^{-7} \mathrm{M}$; lane 4, ANP $10^{-7} \mathrm{M}$; lane 5, Tis 8 ASO $0.5 \mu \mathrm{M}$; lane 6, ET plus Tis 8 ASO $0.25 \mu \mathrm{M}$; lane 7 , ANP and Tis $80.25 \mu \mathrm{M}$. Molecular weight markers (Bio-Rad Laboratories, Richmond, CA) run concurrently are shown by arrows. $(B)$ Effect of ET and bFGF ASO on $\mathrm{bFGF}$ protein. Lane 1, control; lane 2, ET-3; lane 3, ET-3 plus bFGF ASO; lane 4, bFGF ASO; lane 5, ET-3 plus bFGF sense. 

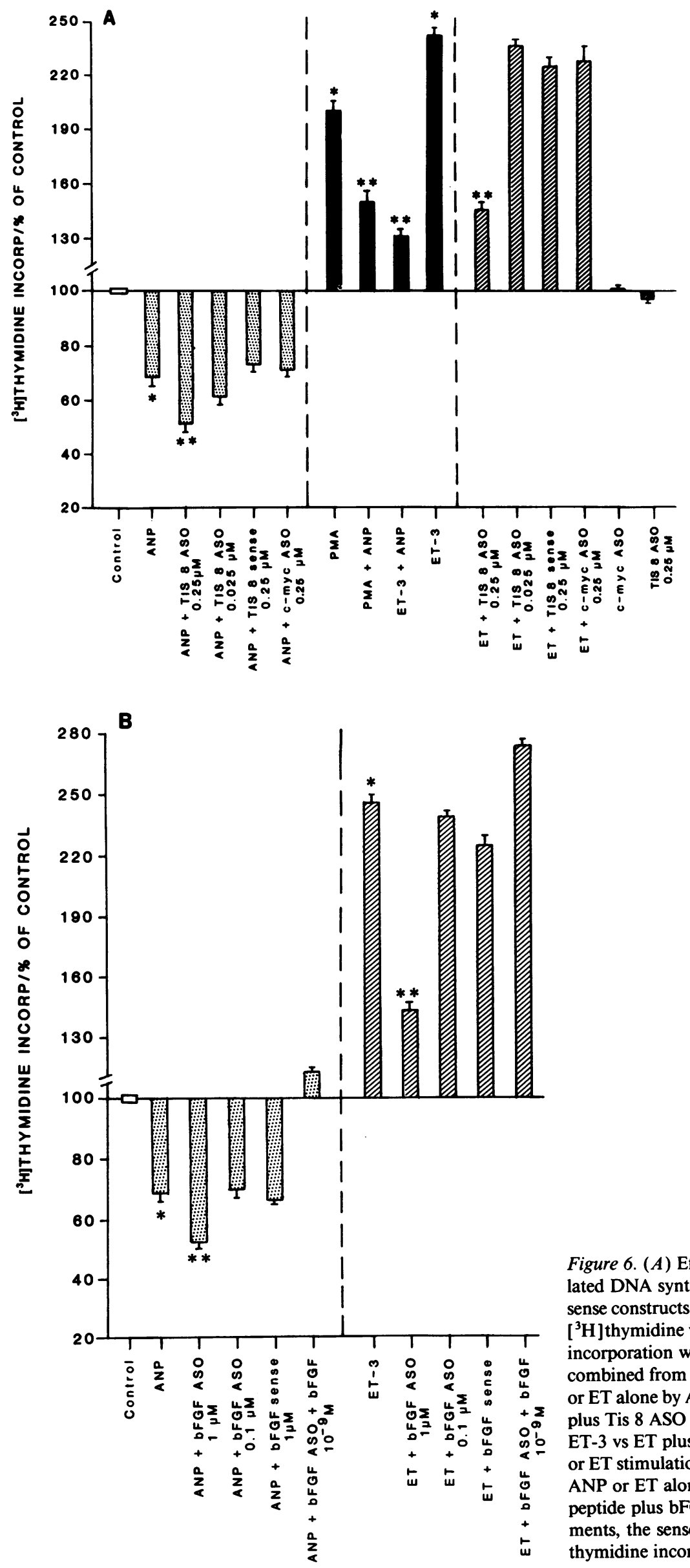

Figure 6. $(A)$ Effects of the Tis 8 ASO on ANP-inhibited or ET-stimulated DNA synthesis in astrocytes. Cells were preincubated with ASO or sense constructs for $18 \mathrm{~h}$, followed by neuropeptides for $24 \mathrm{~h}: 0.5 \mu \mathrm{Ci}$ of [ ${ }^{3} \mathrm{H}$ ] thymidine were added for the last $4 \mathrm{~h}$, and TCA-precipitable nuclear incorporation was determined. Values are the mean \pm SEM from data combined from four separate experiments. ${ }^{*} P<0.05$ for control vs ANP or ET alone by ANOVA plus Scheffe's test, ${ }^{* *} P<0.05$ for neuropeptide plus Tis 8 ASO vs neuropeptide alone, or PMA vs PMA plus ANP, or ET-3 vs ET plus ANP. $(B)$ Effects of the bFGF ASO on ANP inhibition or ET stimulation of astrocyte DNA synthesis. ${ }^{*} P<0.05$ for control vs ANP or ET alone by ANOVA plus Scheffe's test, ${ }^{* *} P<0.05$ for neuropeptide plus bFGF ASO vs neuropeptide alone. In additional experiments, the sense constructs by themselves had no significant effect on thymidine incorporation. 
inhibiting Tis 8. Inhibition of bFGF could then lead to the antigrowth action of ANP.

Effects of bFGF on DNA synthesis. To show that the modulation of bFGF is critical for the regulation of astrocyte proliferation by ANP or ET, we incubated the cells with an ASO to bFGF. The bFGF ASO by itself caused a $29 \pm 4 \%$ inhibition of the basal bFGF protein, based on three combined experiments (Fig. $5 B$ ). ET caused a $75 \pm 5 \%$ increase in bFGF protein production, and the bFGF ASO, but not the sense construct, nearly completely inhibited this stimulation (Fig. $5 \mathrm{~B}$, lanes 2 vs 3 vs 5 ). The bFGF ASO also reversed the ET-augmented thymidine incorporation by $80 \%$, while having an insignificant effect itself (Fig. $6 \mathrm{~B}$ ). The inhibition of DNA synthesis was dose related, and was not seen with the corresponding sense probe. To better ensure that the inhibition of bFGF protein production was the singular mechanism by which this ASO acted, we found that adding exogenous bFGF to the cultured cells completely reversed the action of the bFGF ASO (Fig. $6 B)$.

In contrast, this construct augmented the DNA-inhibitory action of ANP from 36 to $51 \%$. The increased inhibition was dose related, and was reversed by the addition of exogenous bFGF (Fig. $6 \mathrm{~B}$ ). These results indicate that bFGF is likely to mediate the growth modulating actions of the two neuropeptides. To provide additional support for the idea that ANP and ET work through a similar mechanism, we found that ANP inhibited $81 \pm 5 \%$ of the ET-stimulated DNA synthesis (Fig. $6 \mathrm{~A}$ ).

Glioma. We also examined the expression and regulation of Tis 8 by ANP and ET in a rat glioma cell line (C6). Both C6 and human astrocytoma cells are well characterized as having both ANP and ET cell surface receptors $(43,44)$, findings that we confirmed. We found that basal $\mathrm{C} 6$ cells demonstrated a strong expression of the Tis 8 gene (Fig. 7), which was as much as eightfold greater than the expression in comparable amounts of RNA from basal cultured diencephalic astrocytes. Importantly, both ANP and ET-3 failed to inhibit or stimulate, respectively, the expression of this gene.

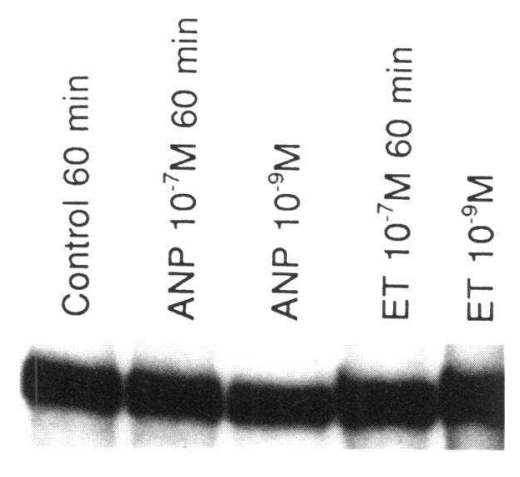

Figure 7. Expression of Tis 8 mRNA in cultured rat glioma cells (C6). Lane 1 , basal expression in control C6 cells $(20$ $\mu \mathrm{g}$ total RNA); lanes $123 \quad 4 \quad 5$

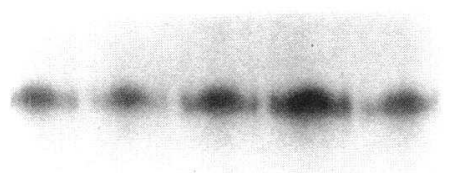

$\begin{array}{lllll}1 & 2 & 3 & 4 & 5\end{array}$

of either ANP or ET on Tis 8 expression in these cells.

\section{Discussion}

Our results indicate that both growth stimulating and inhibiting endogenous neuropeptides modulate DNA synthesis and the proliferation of cultured diencephalic astrocytes $(7,12,13)$ via a common pathway. ET stimulates the immediate early gene, Tis 8 , which then leads to the increased transcription and augmented protein production of bFGF. The stimulation of Tis 8 is necessary for these actions of ET on both bFGF and increased DNA synthesis, since an ASO to Tis 8 reverses these actions: a corresponding sense oligonucleotide for Tis 8 has little effect. This is the first identification, to our knowledge, of a specific immediate early gene/transcription factor that stimulates bFGF production. The importance of Tis 8 is highlighted by the fact that an ASO for c-myc had no effect on ET-stimulated bFGF or thymidine incorporation, even though ET stimulates c-myc expression in the astrocytes.

It has been shown that ET is mitogenic for the vascular smooth muscle cell (45), and stimulates c-fos and c-myc in these and other cells (46). However, it has not been shown which ET-stimulated proteins mediate the proliferative action of this peptide in any cell. In cardiac myocytes, endothelin has been found to cause cardiac hypertrophy and stimulate egr-1 ( Tis 8 ) expression (47). It is unknown, however, whether egr-1 is related to this action of ET. Recently, Neyses et al. showed that ET-1-stimulated cardiac protein synthesis via egr-1 (33). Thus, important growth-related actions of ET in several organs may be mediated through this immediate early gene. As regards astrocyte proliferation, Tis 8 may be a key protein in general since NGF, EGF, and the mitogenic phorbol esters have been shown to stimulate this gene in cultured astrocytes $(12,18,42)$.

The potential important role of bFGF as a key intracellular protein involved in the modulation of astrocyte proliferation by ANP or ET was supported by several of our experiments. First, an ASO for Tis 8 strongly inhibited ET-induced bFGF protein production, and reversed the subsequent stimulation of DNA synthesis by this neuropeptide by $80 \%$, suggesting that the two events are related. Secondly, an antisense oligonucleotide for bFGF inhibited the stimulation of bFGF protein by ET, and strongly prevented the ET-stimulated incorporation of thymidine in the glia. The latter effect was completely reversed by the addition of exogenous bFGF protein. Thirdly, both the Tis 8 ASO and the bFGF ASO augmented the inhibition of bFGF protein production and thymidine incorporation caused by ANP. The latter index of astrocyte proliferation was again reversed by exogenous bFGF.

Basic FGF has been implicated by other investigators to play a role in the growth of astrocytes. For instance, inhibition of bFGF protein synthesis has been shown to significantly decrease the growth of a transformed human astrocyte cell line (48). One of the objections to postulating that bFGF is an important autologous growth factor for glia is that the protein lacks the traditional leader sequence necessary for secretion, and subsequent binding to cell surface FGF receptors expressed on astrocytes (49). However, it may not be necessary for bFGF to be secreted. Acidic and basic FGF each contain a sequence that allows the protein to enter the nucleus of the cell. Basic FGF has been found in the nucleus of astrocytes or endothelial cells, where it increases the production of specific ribosomal protein and may contribute to growth $(50,51)$, potentially through stimulating the production or activation of pro- 
teins that are crucial for induction of the cell cycle. Early studies have also called into question whether bFGF is found in the in vivo brain, as opposed to its abundant presence in cultured astrocytes. More recent findings in brain slices clearly indicate that bFGF is found throughout the central nervous system, localized mainly to astrocytes (52). Thus, the modulation of in vivo astrocyte growth by endogenous proteins could occur via this pathway.

The stimulation of bFGF transcription by ET appears to be mediated through Tis 8 . This might occur as a result of the Tis 8 protein binding to the promoter and transcriptionally transactivating the bFGF gene. However, the canonical egr-1 DNAbinding sequence (CGCCCCCGC) (23) is not present in the bFGF promoter. There is a binding site for the zinc finger protein, sp-1 (CCGCCC) (53) in the bFGF promoter, and this sequence might bind egr-1, since there is a 5-nucleotide, G-Crich overlap of these two sequences. Further detailed analysis is necessary to precisely understand the mechanism of bFGF transcriptional stimulation by ET, as mediated through Tis 8 .

Tis 8 and bFGF appear to mediate the growth inhibitory actions of ANP. ANP selectively inhibited both basal or mitogen-stimulated Tis 8. This probably led to the inhibition of bFGF gene expression and protein production, and to the subsequent decrease in DNA synthesis. These effects were augmented by the ASO to Tis 8 , but not c-myc. Our findings describe ANP as the first identified endogenous protein that negatively modulates Tis 8 production and, thus, provides a model to understand the mechanism of inhibition of this important immediate early gene and protein. As mentioned, we also found that an ASO to bFGF augmented ANP inhibition of DNA synthesis.

ANP also inhibited the augmented thymidine incorporation caused by the astrocyte mitogens, PMA, or endothelin. Since both these substances were shown to stimulate Tis 8, our findings indicate that ANP probably works through this same pathway. There are few, well characterized anti-growth factors for astrocytes $(54,55)$, and thus ANP provides a means to understand the important steps in the restraint of growth in these cells, assuming that these results are extrapolatable to the in vivo brain.

Our findings in the glioma cells indicate that ANP can not inhibit and endothelin can not stimulate the basal high expression of this gene. This suggests that the "normal" control of Tis 8 in cultured glia is lacking in transformed astrocytes. Overexpression of oncogenes/growth factors is often associated with the development of cancer (15), and therefore, the strong basal expression of this gene might contribute to the development or maintenance of growth in these cells. Specifically, we postulate that the alteration of inhibitory control of this protein contributes to the relatively unregulated proliferation of these cancer cells. Support for this idea comes from the participation of egr-1 (Tis 8) in the development/growth of a subset of Wilm's tumors. These tumors are associated with the loss of a probable tumor suppressor gene (WT-1), whose protein product appears to inhibit the ability of egr-1 to act as a positive transcriptional factor by competing for DNA binding sites (56). This implies that the loss of inhibitory regulation of egr-1 transcriptional action underlies the development and growth of these tumors. Thus, we speculate that the strong and abnormally regulated expression of Tis 8 in cultured glioma cells serves a similar function. Additional studies are needed to understand the mechanisms of the loss of Tis 8 regulation by ANP and ET, but such information in these cells may lead to important insights into the biology of these tumors.

Our findings indicate a novel pathway by which growth inhibitory or stimulatory neural proteins can modulate astrocyte proliferation in vitro. The deduced mechanism of action for ANP or ET may provide a schema to understand the critical events of astrocyte proliferation and the response to growth regulating proteins.

\section{Acknowledgments}

We thank M. Rossi and A. Pedram for technical assistance, and $\mathrm{H}$. Hershman for helpful discussions. This work was supported by a Merit Review Grant from the Veterans Administration, grants from both the National and California American Heart Associations, and National Institutes of Health grant 1RO1HL50161 (E. R. Levin).

\section{References}

1. Hengerer, B., D. Lindholm, R. Heumann, U. Ruther, E. F. Wagner, and H. Thoenen. 1990. Lesion-induced increase in nerve growth factor mRNA is mediated by c-fos. Proc. Natl. Acad. Sci. USA. 87:3899-3903.

2. Mocchetti, I., M. A. DeBernardi, A. M. Szekely, H. Alho, G. Brooker, and E. Costa. 1989. Regulation of nerve growth factor biosynthesis by B-adrenergic receptor activation in astrocytoma cells: A potential role of c- fos protein. Proc. Natl. Acad. Sci. USA. 86:3891-3895.

3. Kouzarides, T., and E. Ziff. 1989. Leucine zippers of fos, jun and GCN4 dictate dimerization specificity and thereby control DNA binding. Nature (Lond.). 340:568-571.

4. Standaert, D. H., P. Needleman, and C. B. Saper. 1986. Organization of atriopeptin-like immunoreactive neurons in the central nervous system of the rat. J. Compar. Neurol. 253:315-341.

5. Levin, E. R., P. J. Isackson, and R.-M. Hu. 1991. Endothelin increases atrial natriuretic peptide production in cultured rat diencephalic neurons. Endocrinology. 128:2925-2930.

6. de Vente, J., J. G. J. M. Bol, and H. W. M. Steinbusch. 1989. CGMP-producing, atrial natriuretic factor-responding cells in the rat brain. Eur. J. Neurosci. 1:436-460.

7. Levin, E. R., and H. J. L. Frank. 1991. Natriuretic peptides inhibit astroglial proliferation: mediation by C receptor. Am. J. Physiol. 261:R453-R457.

8. Lee, M. E., S. M. de la Monte, S. C. Ng, K. D. Bloch, and T. Quertermous. 1990. Expression of the potent vasoconstrictor endothelin in the human central nervous system. J. Clin. Invest. 86:141-147.

9. Raizada, M. K., B. Kimura, and M. I. Philips. 1990. Immunoreactive atrial natriuretic peptide in neuronal and glial cells of spontaneously hypertensive rat brain. Am. J. Physiol. 258:C109-C114.

10. MacCumber, M. W., C. A. Ross, B. M. Glaser, and S. H. Snyder. 1989. Endothelin: visualization of mRNAs by in situ hybridization provides evidence for local action. Proc. Natl. Acad. Sci. USA. 86:7285-7290.

11. Marsault R., P. Vigne, J.-P. Breittmayer, and C. Frelin. 1990. Astrocytes are target cells for endothelins and sarafotoxin. J. Neurochem. 54:2142-2144.

12. Supattapone, S., A. V. M. Simpson, and C. C. Ashley. 1989. Free calcium rise and mitogenesis in glial cells caused by endothelin. Biochem. Biophys. Res. Commun. 165:1115-1122.

13. Levin, E. R., H. J. L. Frank, and A. Pedram. 1992. Endothelin receptor expression in fetal rat diencephalon. J. Neurochem. 58:659-666.

14. Levin, E. R. 1991. Atrial natriuretic peptide and endothelin: interactions in the central nervous system and periphery. Mol. Cell Neurosci. 2:189-201.

15. Bishop, J. M. 1987. The molecular genetics of cancer. Science. 235:305311.

16. Caubet, J. F. 1989. c- fos proto-oncogene expression in the nervous system during mouse development. Mol. Cell Biol. 9:2269-2272.

17. Carbone, M., and A. S. Levine. 1990. Oncogenes, antioncogenes and the regulation of cell growth. Trends Endocrinol. Metabol. 1:248-253.

18. Arenander, A. T., J. de Vellis, and H. R. Herschman. 1989. Induction of c-fos and TIS genes in cultured rat astrocytes by neurotransmitters. J. Neurosci. Res. 24:107-114.

19. Milbrandt, J. 1987. A nerve growth factor-induced gene encodes a possible transcriptional regulatory factor. Science (Wash. DC). 238:797-799.

20. Sukhatme, V. P., X. M. Cao, L. C. Chang, C.-H. Tsai-Morris, D. Stamenkovich, P. C. Ferreira, D. R. Cohen, S. A. Edwards, T. B. Shows, and T. Curran. 1988. A zinc-finger encoding gene coregulated with c-fos during growth and differentiation, and after cellular depolarization. Cell. 53:37-43.

21. Lemaire, P., O. Revelant, R. Bravo, and P. Charnay. 1990. Two mouse genes encoding potential transcription factors with identical DNA-binding do- 
mains are activated by growth factors in cultured cells. Proc. Natl. Acad. Sci USA. 85:4691-4965.

22. Christy, B. A., L. F. Lau, and D. Nathans. A gene activated in mouse 3T3 cells by serum growth factors encodes a protein with "zinc finger" sequences. Proc. Natl. Acad. Sci. USA. 85:7857-7861.

23. Sukhatme, V. P. 1990. Early transcriptional events in cell growth: the EGR family. J. Am. Soc. Nephrol. 1:859-866.

24. Lim, R., B. C. Varnum, and H. R. Herschman. 1987. Cloning of tetradecanoyl phorbol-ester induced "primary response" sequences and their expression in density arrested density-arrested Swiss 3T3 cells and a TPA non-proliferative variant. Oncogene. 1:263-270.

25. Alitalo, K., M. Schwab, C. C. Lin, H. E. Varmus, and J. M. Bishop. 1983. Homogenously staining chromosomal regions contain amplified copies of abundantly expressed cellular oncogene (c-myc) in malignant neuroendocrine cells from a human colon carcinoma. Proc. Natl. Acad. Sci. USA. 80:1707.

26. Xu, Y.-H., S. Ishii, A. J. L. Clark, M. Sullivan, R. K., Wilson, D. P. Ma, B. A. Roe, G. T. Merling, and I. Pastan. 1984. Human epidermal growth factor receptor cDNA is homologous to a variety of RNAs overproduced in A431 carcinoma cells. Nature (Lond.). 309:806-810.

27. Esch, F., A. Baird, N. Ling, N. Veno, F. Hill, L. Denoroy, R. Klepper, D. Gospodarowicz, P. Bohlen, and R. Guillemin. 1985. Primary structure of bovine pituitary fibroblast growth factor (FGF) and comparison with the amino-terminal sequence of bovine brain acidic FGF. Proc. Natl. Acad. Sci. USA. 82:65076511 .

28. Majesky, M. W., M. J. A. P. Daeman, and S. M. Schwartz. 1990. $\alpha_{1}$-adrenergic stimulation of platelet-derived growth factor A-chain gene expression in rat aorta. J. Biol. Chem. 265:1082-1088.

29. Bach, M. A., C. T. Roberts, Jr., E. P. Smith, and D. Leroith. 1990. Alternative splicing produces messenger RNAs encoding insulin-like growth factor-1 prohormones that are differentially glycosylated in vitro. Mol. Endocrinol. 6:899904.

30. Levin, E. R., H. J. L. Frank, R. Gelfand, S. Loughlin, and G. Kaplan. 1990. Natriuretic peptide receptors in cultured rat diencephalon. J. Biol. Chem. 265:10019-10024.

31. Hu, R.-M., E. R. Levin, A. Pedram, and H. J. L. Frank. 1992. Atrial natriuretic peptide inhibits the translation and secretion of endothelin from cultured bovine aortic endothelial cells: Mediation through $\mathrm{C}$ receptors. J. Biol. Chem. 267:17384-17389.

32. Hu, R.-M., E. R. Levin, A. Pedram, and H. J. L. Frank. 1993. Insulin increases the production and secretion of endothelin from cultured bovine endothelial cells. Diabetes. 42:351-358.

33. Neyses, L., J. Nouskas, and H. Vetter. 1991. Inhibition of endothelin-1 induced myocradial protein synthesis by an antisense oligonucleotide against the early response gene-1. Biochem. Biophys. Res. Commun. 181:22-27.

34. Richardson, W. D., Pringle, N. Moseley, M. J. Westermark, B., and M. Dubois-Dalcq. 1988. A role for platelet-derived growth factor in normal gliogenesis in the central nervous system. Cell. 53:309-319.

35. Raff, M. C., L. E. Lillien, W. D. Richardson, J. F. Burne, and M. D. Noble. 1988. Platelet-derived growth factor from astrocytes drives the clock that times oligodendrocyte development in culture. Nature (Lond.). 333:562-565.

36. Noble, M., K. Murray, P. Stoobant, M. Waterfield, and P. Riddle. 1988. Platelet-derived growth factor promotes division and mobility and inhibits premature differentiation of the oligodendrocyte/type 2 astrocyte progenitor cell. Nature (Lond.). 333:560-562.

37. Libermann, T. A., H. R. Nusbaum, N. Razon, R. Kris, I. Lax, H. Soreq, N. Whittle, M. D. Waterfield, A. Ullrich, and J. Schlessinger. 1985. Amplification, enhanced expression, and possible rearrangement of EGF receptor gene in primary human brain tumors of glial origin. Nature (Lond.). 313:144-147.

38. Leonir, D., and P. Honegger. 1983. Insulin-like growth factor I (IGFI) stimulates DNA synthesis in fetal rat brain cell cultures. Dev. Brain Res. 7:205213.

39. Ballotti, R., F. C. Nielsen, N. Pringle, A. Kowalski, W. D. Richardson, E. van Obberghen, and S. Gammeltoft. 1987. Insulin-like growth factor I in cultured rat astrocytes: expression of the gene and receptor tyrosine kinase. $E M B O$ (Eur. Mol. Biol. Organ.) J. 6:3633-3639.

40. Ferra, N., F. Ousley, and D. Gospadoaowicz. 1988. Bovine brain astrocytes express basic fibroblast growth factor: a neurotrophic and angiogenic factor. Brain Res. 462:223-232.

41. Emoto, N., A.-M. Gonzalez, P. A. Walicke, E. Wada, D. M. Simmons, S. Shimasaki, and A. Baird. 1989. Basic fibroblast growth factor (FGF) in the central nervous system: identification of specific loci of basic FGF expression in rat brain. Growth Factors. 21-29.

42. Arenander, A. T., R. W. Lim, B. C. Varum, R. Cole, J. de Vellis, and H. R. Herschman. 1989. TIS gene expression in cultured astrocytes: multiple pathways of induction by mitogens. J. Neurosci. Res. 23:257-265.

43. Cozza, E. M., M. C. Vila, and C. E. Gomez-Sanchez. 1990. ET-1 receptors in C-6 cells: homologous down-regulation and modulation by protein kinase $\mathrm{C}$. Mol. Cell Endocrinol. 155-164.

44. Lyall, F., A. J. Balmforth, and J. J. Morton. 1988. Specific binding of atrial natriuretic peptide increase cyclic GMP levels in human astrocytoma cells. $J$. Endocrinol. 315-321.

45. Bobik, A., A. Grooms, J. A. Millar, A. Mitchell, and S. Grinpukel. 1990. Growth factor activity of endothelin on vascular smooth muscle. Am. J. Physiol. C408-C415.

46. Simonson, M. S., S. Wann, P. Mene, G. R. Dubyak, M. Kester, Y. Nakazoto, J. R. Sendoe, and M. J. Dunn. 1989. Endothelin stimulates phospholipase $\mathrm{C}, \mathrm{Na}^{+} / \mathrm{H}^{+}$exchange, c-fos expression, and mitogenesis in rat mesangial cells. $J$. Clin. Invest. 83:708-712.

47. Shubeita, H. E., H. N. Harris, P. M. McDonough, K. U. Knowlton, C. Glembotski, J. H. Brown, and K. R. Chien. 1990. Endothelin induction of sarcomere assembly and cardiac gene expression in ventricular myocytes: a paracrine mechanism for myocardial cell hypertrophy. J. Biol. Chem. 265:20555-20562.

48. Morrison, R. S. 1991. Suppression of basic fibroblast growth factor expression by antisense oligodeoxynucleotides inhibits the growth of transformed human astrocytes. J. Biol. Chem. 266:728-734.

49. Burgess, W. H., and T. Maciag. 1989. The heparin-binding (fibroblast) growth factor family of proteins. Annu. Rev. Biochem. 58:575-606.

50. Imamura, T., K. Engleka, X. Zhan, Y. Tokita, R. Forough, D. Roeder, A Jackson, J. A. M. Maier, T. Hla, and T. Maciag. 1990. Science (Wash. DC) 1567-1570.

51. Baldin, V., A. Roman, and I. Bosc-Bierne. 1990. Translocation of bFGF to the nucleus is $\mathrm{G} 1$ phase cell cycle specific in bovine aortic endothelial cells. EMBO (Eur. Mol. Biol. Organ.) J. 9:1511-1517.

52. Woodward, W. R., R. Nishi, C. K. Meshul, T. E. Williams, M. Coulombe and F. P. Eckenstein. 1992. Nuclear and cytoplasmic localization of basic fibroblast growth factor in astrocytes and CA2 hippocampal neurons. J. Neurosci. 12:142-152.

53. Jones, K. A., J. T. Kadonaga, P. A. Luciw, and R. Tijan. 1986. Activation of the AIDS retrovirus promoter by the cellular transcription factor, Spl. Science (Wash. DC). 242:755-759.

54. Rogister, B., P. Leprince, V. Bonhomme, J. M. Rigo, P. Delree, A. Colige, and G. Moonen. 1990. Cultured neurons release an inhibitor of astroglia proliferation (astrostatine). J. Neurosci. Res. 58-70.

55. Nieto-Sampedro, M. 1988. Astrocyte mitogen inhibitor related to epidermal growth factor receptor. Science (Wash. DC). 240:1784-1786.

56. Madden, S. L., D. M. Cook, J. F. Morris, A. Gashler, V. P. Sukhatme, and F. J. Rauscher. 1991. Transcriptional repression mediated by the WT-1 Wilms tumor gene product. Science (Wash. DC). 253:1550-1553. 